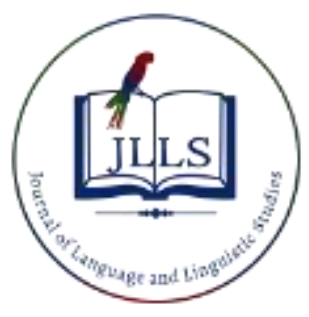

\title{
Long distance scrambling and operator movement in Turkish
}

\author{
Sinan Çakır $^{\mathrm{a}} *$ (iD) \\ ${ }^{a}$ Necmettin Erbakan University,Department of Linguistics, Konya, 42090, Turkey
}

\section{APA Citation:}

Çakır, S. (2020). Long distance scrambling and operator movement in Turkish. Journal of Language and Linguistic Studies, 16(1), 440-457. Doi: $10.17263 /$ jlls. 712873

Submission Date:02/10/2019

Acceptance Date:06/02/2020

\begin{abstract}
The present study focuses on long distance scrambling and operator movement from embedded clauses to sentence initial position in Turkish. It proposes that the scrambling of the arguments out of the complement clauses is possible due to the fact that such phrases move cyclically through phases in Turkish. It is also asserted that the adjuncts that have nominal features can scramble to the sentence initial position by using the spec DP position as an escape hatch similar to the arguments. On the other hand, the Phase Impenetrability Condition is violated in the movement of the non-nominal adjuncts out of such clauses. In the analysis of the adjunct clauses, it is asserted that the Late Adjunction Hypothesis successfully explains all types of extractions out of such clauses in Turkish. Arguments, adjuncts or their operators cannot be moved out of relative clauses or adverbial clauses since these clauses adjoin to the derivation post-cyclically. Turkish data support the assertion that extractions out of adjuncts are banned universally.
\end{abstract}

(C) 2020 JLLS and the Authors - Published by JLLS.

Keywords: Turkish; operator movement; scrambling; PIC; LAH

\section{Introduction}

The term "scrambling" was first defined by Ross (1967) as "free word order". According to him, it is a stylistic rule which is optionally applied in grammar. Yet, the optional movement of the elements conflicts with the last resort principle of the Minimalist Program, according to which an element cannot move unless it has to do so. Within the Minimalist Program, scrambling has been considered to be an obligatory operation which is applied for checking purposes. The constituents are claimed to scramble to different sentence positions to check features such as focus or topic.

Turkish is a head-final SOV language, which allows constituents to scramble to various positions in the construction. The driving force of the movement is argued to be information structure. It is commonly accepted that scrambling to the sentence initial position marks the constituent as the topic,

${ }^{*}$ Sinan Çakır. Tel.: +090-332-325-2057

E-mail address: sinancakir@erbakan.edu.tr 
the immediately preverbal position marks it as the focus, and the post-verbal position as the background information in this language (Erguvanl1, 1984).

Long distance scrambling in Turkish is motivated by the [Topic] feature of $\mathrm{C} 0$ and an XP moves to the spec position of this node to check this uninterpretable feature (Özsoy, 2005, p.02). Akan (2009) is another scholar who states that scrambling in Turkish is a feature-driven operation. As he asserts, it is a syntactic operation rather than an optional operation, which makes it compatible with the last resort principle. Similarly, in another study, Özsoy (2009) focuses on long distance scrambling of wh-phrases. As she argues, in such structures, the displaced constituent is attracted by an uninterpretable feature of the probe, targeting the specifier position of the relevant head. According to her, this position is the Spec CP position (or TopP in accordance with Rizzi, 1997) of the matrix clause from where the long distance scrambled wh-phrase sets up a semantically significant operator-variable relation, binding its lower copy in the merge position, moving successive cyclically through the intermediary specifiers to matrix Spec CP.

With regard to wh-questions, Turkish is a wh-in-situ language. The wh-phrases do not have to move overtly to sentence initial position. For wh-in-situ languages, alternative to the covert movement approach of Huang (1982), the unselective binding approach (Aoun and Li, 1993) claims that wh-words are co-indexed and interpreted by means of a question operator in overt syntax. This approach successfully explains the adjunct $\&$ argument asymmetry observed in Chinese ${ }^{\dagger}$. As they assert, the relation between the wh-phrase and the Qu-operator is a bindee-binder relation. Adjuncts (but not arguments) require a local Qu-operator. In cases where in-situ adjuncts are in islands, the associated Quoperator must also be generated in islands. The subsequent movement of the Qu-operator can thus lead to island violations.

Arslan (1999) and Görgülü (2006) adopted the Unselective Binding Approach to Turkish case. According to these scholars, wh-expressions that stay in-situ are bound with a $[\mathrm{Qu}]$-operator in overt syntax. Görgülü (2006) provides evidence for the fact that operator movement approach is more suitable for Turkish through the analysis of (non)existence of "ki" particle in CPs. He argues that the interpretation of the $w h$-words in Turkish is determined by the (non)existence of the Gen(eric)-operator, the interaction of the Gen-operator and the Negative operator, and the (non)existence of the particle $k i$ in the C-domain He proposes that wh-words in Turkish are variables bound by different operators and their interpretations are determined by the nature of the operators that bind them (p. 33). As Arslan (1999) puts forward, while the LF movement analysis can explain the different behaviors of adjuncts

\footnotetext{
${ }^{\dagger}$ Aoun and $\mathrm{Li}$ (1993, p.203) exemplify the argument \& adjunct asymmetry observed in Chinese as follows:

(1) a. Ni xihuan sheixie deshu?

You like who write DE book

'Who(x) such that you like the book $\mathrm{x}$ wrote?'

b. *Nixihuantaweishenmexie de shu?

You like he why write DE book

'Why(x) you like the book he wrote $\mathrm{x}$ ?'
}

Both (1a) and (1b) are subject to classical Complex NP Island Constraint. While the interpretation of the argument wh-word is grammatical within this island structure, the interpretation of the wh-adjunct results in ungrammaticality. A similar asymmetry is observed in Turkish. Özsoy (1996) provides the following examples:

$\begin{array}{cccc}\text { (2) a [[Kim-in } & \text { yaz-diğ-1] } & \text { mektub]-u } & \text { oku-du-n? } \\ \text { Who-GEN write-FN-3SG } & \text { letter-ACC } & \text { read-PAST-2SG } \\ \text { *'Who did you read [the letter[\{who\} } \text { wrote]]?' } & \\ \text { b *[[Adam-1n neden yaz-diğ-1] } & \text { mektup] } & \text { uzun? } \\ \text { Man-GEN why } & \text { write-FN-3SG letter } & \text { long } \\ \text { *'Why is [the letter [the man wrote }\{w h y\}]] \text { long?' } & \end{array}$

Similar to Chinese, while (2a) is grammatical, (2b) is not. 
and arguments within the structures that are subject to Adjunct Island Constraint and Complex NP Island Constraint, it does not provide an adequate explanation for some other cases. According to her, such structures involve the interpretation of the wh-phrases within postpositional phrases and sentential subjects and the constructions in which the wh-elements co-occur with the operator yalnizca 'only'. The operator movement approach, on the other hand, explains successfully all these structures (p .53). For these reasons, the present paper favors the operator movement approach over the covert movement approach.

Scrambling and operator movement in Turkish are not without restrictions. Long distance extractions are subject to island effects and the movement of some elements out of lower clauses results in ungrammaticality. The present paper aims to provide minimalist explanations for the island effects which are observed in the movement of the elements from embedded clauses to sentence initial positions in accordance with the Phase Impenetrability Condition and the Late Adjunction Hypothesis. In the paper, long distance extractions from complement clauses (Complex NPs, factive and non-factive nominalized clauses) and adjunct clauses (relative clauses and adverbial clauses) are analyzed separately.

\section{Complement Clauses in Turkish}

There are basically two types of complement clauses in Turkish: those whose predicate is marked with a factive nominal -DIK and those with a predicate which is marked with the non-factive nominal -mA. As Kornfilt (2003) also states, both types are c-commanded with a DP node:

$\begin{array}{rrlll}\text { (3) a. Kerem } & \text { [DP [Merve'nin } & \text { okula } & \text { git-tiğ-i]-ni }] & \text { biliyor. } \\ \text { Kerem } & \text { Merve-GEN } & \text { school-DAT } & \text { go-FN-3SG-ACC } & \text { know-PROG }\end{array}$

'Kerem knows that Merve went to school.'

b. Kerem [DP [Merve'nin okula git-me-si]-ni] istiyor.

Kerem Merve-GEN school-DAT go-NFN-3SG-ACC want-PROG

'Kerem wants Merve to go to school.'

Aygen $(2002 ; 2011)$ argues that factive nominalized complement clauses in Turkish are complex NPs with a phonologically unrealized nominal head. According to her, this null head can be filled with a lexical noun from a restricted list: fact, truth etc. (4a) and (4b) below exemplify these cases respectively:

(4) a. Ecem [DP [Tolga'nın Uğur'u ara- dığ-1]-n1] öğrendi.

Ecem Tolga-GEN Uğur-ACC phone-FN-3SG-ACC learn-PAST

'Ecem learnt [that Tolga phoned Uğur].'

b. Ecem [DP[Tolga'nın Uğur'u ara-dığ-1] söylenti-leri-ni] öğrendi.

Ecem Tolga-GEN Uğur-ACC phone-FN-3SG rumor-3PL-ACC learn-PAST

'Ecem learnt [the rumors [that Tolga phoned Uğur]]'.

The embedded clauses in (4a) and (4b) have a DP in their highest functional layer which needs case like any DP (Aygen, 2002; Kornfilt, 2003; 2005). In (4a), D0 does not contain a lexical noun but an 
accusative morpheme. In (4b), this node contains the lexical noun "söylentileri" (rumors) along with the accusative morpheme.

As Gürel (2003) also argues, the nominalized constructions in Turkish behave exactly like lexical DPs in many respects such as their internal morphology, case marking etc. She provides the following examples:

(5) a. Elif [onun anne-si]-ni öptü.

Elif s/he-GEN mother-3SG-ACC kiss-PAST

'Elif kissed her/his mother.'

b. Elif [onun gel-diğ-i]-ni söyledi.

Elif s/he-GEN come-FN-3SG-ACC say-PAST

'Elif said that s/he had come.'

Hence, as Aygen (2002; 2011), Kornfilt (2003) and Gürel (2003) assert, the embedded clauses in Turkish are DPs rather than CPs. Yet, the following question remains unanswered: why should they be classified as DPs rather than NPs? The answer for this question comes from Arslan Kechriotis (2009). She argues that Turkish has a DP projection even though it lacks overt determiners/articles. She proposes that Turkish referential nominals possess a Determiner Phrase (DP) layer where D0 assigns referentiality to the nominal. DP in turn is argued to select a Number Phrase (NumP)/Classifer Phrase (ClP) both subcategorizing for an NP. She provides semantic and syntactic evidence for the existence of a DP projection in Turkish through the analyses of (1) the behavior of [bir NP] constructions, (2) the island effects in scrambling and (3) the ECM constructions in Turkish (See the related work for more information on this issue). The referential nominals are case-marked in contrast to non-referential ones in this language. As Arslan Kechriotis (2009) argues, there is a syntactic difference between referential andnon-referential nominals in Turkish, the former being DP and the latter NP. Hence, since all nominalized embedded clauses are case-marked in Turkish, they are DPs in this language.

In Turkish, the DP dominating the embedded clause constitutes an island for the upper movement of the elements:

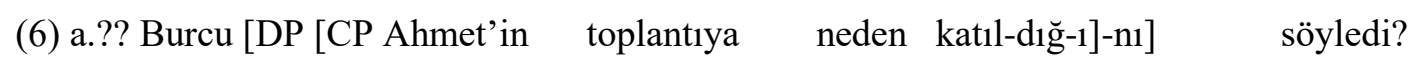

Burcu Ahmet-GEN meeting-DAT why attend-FN-3SG-ACC say-PAST

'Why did Burcu say [that Ahmet attended the meeting \{why\}]?'

b.??Burcu [DP [CP Ahmet'in toplantıya neden kat1l-ma-s1]-n1] istiyor?

Burcu Ahmet-GEN meeting-DAT why attend- NFN-3SG-ACC want-PROG

'Why does Burcu want [Ahmet to attend the meeting \{why\}]?'

Although (6a) and (6b) are not subject to any of the classical island constraints, the movement of the wh-operators from embedded clauses to matrix spec CP positions leads to a degradation. This movement is, in fact, subject to weak Complex DP Island Constraint. The DP which exists in the highest functional layer of the embedded clause poses an island for the upper movement of the elements (Author, 2017). When the DP contains a lexical noun, the interrogative sentence becomes more degraded:

(7) * Burcu [DP[CP Ahmet'in toplantıya neden katıl-dığ-1] iddia-ları-n1] yalanladı?

Burcu Ahmet-GEN meeting-DAT why attend-FN-3SG claim-3PL-ACC deny-PAST

* 'Why did Burcu deny [the claims [that Ahmet attended the meeting \{why\}]]?' 
(7) is subject to classical Complex NP Island Constraint. The reason for the ungrammaticality in (6) and (7) can be explained through the Phase Impenetrability Condition (the PIC hereafter). In the Phase Theory, DPs are assumed to be phases ${ }^{\ddagger}$ along with CPs and vPs (Chomsky, 2001; 2008; Adger, 2003; Boskovic, 2013 and many others). In this paper, it is proposed that the DP node in (6) and (7) cannot host a [uwh] feature which would allow wh-operators to use its spec position as an escape hatch.

The question that arises at this point is whether intermediate phase-edge stops are feature-driven or not. There are two opposing views on this issue. According to Heck and Müller (2000), Chomsky (2000) and Boskovic (2007), intermediate movement is triggered via a different mechanism than terminal movement. For instance, according to Boskovic (2007), such movement is not feature-driven, but rather an economy-driven shortest move effect. On the other hand, Chomsky (1995), Skinner (2005), Abels (2012), Baier (2014) and van Urk and Richards (2015) claim that intermediate movement is featuredriven as well. According to the Last Resort Principle, any movement is driven by feature checking (Chomsky, 1995, p. 253). Hence, as Biskup (2007) also asserts, in the case of successive-cyclic movement, the movement steps to the intermediate positions should be feature-driven as well. Similarly, Skinner (2005) puts forward the following argument to support the claim that intermediate stops are feature-driven. As he argues, the movement of a wh-phrase is not triggered until its head is inserted into the derivation. According to him, this scenario does not work under a phasal analysis of syntactic derivation, for several reasons. First, if the wh-phrase contains an uninterpretable wh-feature, and that it is left in-situ until motivated to move by the matrix complementizer, the phase containing the whphrase is presumably sent to PF while still containing an uninterpretable wh-feature. This is contra the condition that phases should not contain any uninterpretable features when they are delivered to the PF component (Chomsky, 2001). More importantly, the PIC disallows access to the wh-phrase at the point of insertion of the matrix complementizer, since the wh-phrase is too deeply embedded in a lower phase, and thus unavailable for movement operations. Hence, he puts forward that intermediate phase-edge stops must also contain strong uninterpretable wh-features. The present paper favors the claim that such stops are feature-driven as well.

To illustrate, (6a) is derived in the following stages: Firstly, the wh-operator merges to the derivation along with the wh-phrase within the embedded clause. Then, it moves to the spec position of the lower $\mathrm{CP}$ to check the [uwh] feature of $\mathrm{C} 0$. When the derivation goes to spell out, it is visible for further operations as it is at the edge of the $\mathrm{CP}$ phase. This gives us the following structure:

[CP wh-op [世wh][TP Ahmet'in toplantıya neden \{wh-op\} katıldı̆̆ı]]

The embedded CP then merges with the D0 node, which constitutes another phase. This D0, however, does not host a [uwh] feature, which would allow the wh-operator to move its specifier position. When the derivation goes to spell out in the DP phase, the wh-operator becomes inaccessible for further operations:

[DP [CP wh-op [uwh][TP Ahmet'in toplantıya neden \{wh-op\} katıldığı]]n1]

\footnotetext{
†Chomsky $(2000 ; 2001)$ suggests that DPs are also phases, and a number of recent papers agree with this proposal. (Boškovic 2005; 2013; Den Dikken 2007; Despic 2011; Heck et al. 2008). According to the PIC, an XP can move out of a YP only if it first moves to its spec position. Hence, as Boskovic (2013) also asserts, the movement out of DP must proceed via spec DP. In a similar vein, Punske (2011) puts forward that this analysis explains the "semantic" restrictions on extraction out of a DP. Extraction out of noun phrase has been known to be highly constrained since the earliest work in generative syntax. Since phases are spell-out points, only elements in the edge of the phase are available for further derivation. Hence, if DPs are not phases, it is possible to move anything out of them, which is obviously not the case for some languages such as Turkish.
} 
In the rest of the derivation, the [uwh] feature of the matrix $\mathrm{C}$ cannot be checked and the derivation results in ungrammaticality:

[CP [uwh] [TP Burcu [vp [DP [CP wh-op [uwh][TP Ahmet'in toplantıya neden \{wh-op\} katıldı söyle]di]]

Unlike the adjunct wh-operators in (6) and (7), the operators of the wh-arguments are not subject to island effects in Turkish:

(8) a. Burcu [DP [CP kimin toplantiya kat1l-ma-s1]-n1] istiyor?

Burcu who-GEN meeting-DAT attend-NFN-3SG-ACC want-PROG

* 'Who does Burcu want [\{who $\}$ to attend the meeting]?'

b. Burcu [DP [CP kimin toplantıya katıl-dığ-1-]-n1] yalanladı?

Burcu who-GEN meeting-DAT attend-FN-3SG-ACC deny-PAST

* 'Who did Burcu deny [that \{who\} attended the meeting]?'

c. Burcu [DP[C kimin toplantıya katıl-dı̆̆-1] iddia-ları-n1] yalanladı?

Burcu who-GEN meeting-DAT attend-FN-3SG claim-3PL-ACC deny-PAST

* 'Who did Burcu deny [the claims [that $\{$ who $\}$ attended the meeting]]?'

As Aoun and Li (1993) put forward, the operator of a wh-argument merges into the derivation directly in matrix $\mathrm{CP}$ position ${ }^{\S}$ to check its interpretable [wh] feature with the [uwh] feature that exists in this node. Therefore, in (8), the PIC is not violated since wh- operators in these sentences do not cross the DP node.

To generalize these assertions, an XP cannot be extracted out of a DP in Turkish. Otherwise, it violates the PIC. However, in overt scrambling cases, a phrase can move from a complement clause to the edge of the main clause, which should not be possible under this generalization. These overt scrambling cases are analyzed below:

\subsection{Long Distance Scrambling \& Operator Movement out of Complement Clauses}

In Turkish, it is observed that both the wh-arguments such as kimin (who-GEN, kimi (who-ACC) and neyi (what-ACC) and their non-wh counterparts can move from the embedded complement clause to the matrix $\mathrm{CP}$ position (or TopP position) without yielding ungrammaticality:

(9) a. [TopP Ŭgur'u [ TP Ecem [DP[CP Tolga'nın \{Uğur'u\} ara-dığ-1]-nı] biliyor]]

Uğur-ACC Ecem Tolga-GEN phone-FN-3SG-ACC know-PROG

'Ecem knows [that Tolga phoned Ŭgur].'

b. [TopP Kimi [TP Ecem [DP [CP Tolga'nın \{kimi\} ara-dığ-1]-n1] biliyor]]?

\footnotetext{
${ }^{\S}$ Aoun and Li (1993) claim that the operators of the wh-arguments are directly generated within the matrix CPs since such phrases are lexically-governed. On the other hand, the adjunct wh-operators are generated along with the wh-phrases and move to matrix CP position. According to them, this movement is subject to island effects. They make these assertions to explain the argument $\&$ adjunct asymmetry observed in Chinese. This proposal seems to be valid for Turkish as well, which is another whin-situ language. Yet, the reason for this asymmetry is explained through GB-based "lexical government" phenomenon. Since "government" is abandoned in the Minimalist Program, it is necessary to provide a minimalist explanation for the question why the operators of arguments and adjuncts merge into the derivation in different nodes. In this paper, this point is left for further research.
} 
Who-ACC Ecem Tolga-GEN phone-FN-3SG-ACC know-PROG

'Who does Ecem know [that Tolga phoned \{who\}]?'

(10) a. [TopP Uğur'u [TP Elif [DP[CP Murat'ın\{Uğur'u\}öldür-düğ-ü] iddia-ları-na] inanmıyor]] Uğur-ACC Elif Murat-GEN kill-FN-3SG claim-3PL-DA believe-NEG-PROG 'Elif does not believe in [the claims [that Murat killed Ŭgur]].'

b. [TopP Kimi [TP Elif [DP [CP Murat'ın\{kimi\}öldür-düğ-ü] iddia-ları-na] inanmıyor?]

Who-ACC Elif Murat-GEN kill-FN-3SG claim-3PL-DAT believe-NEG-PROG

* 'Who does Ecem not believe in [the claims [that Murat killed \{who\}]]?'

The following question arises at this point: If DPs are also phases, how is it possible for these scrambled phrases to pass the DP phase without violating the PIC?

It is proposed here that the D0 that c-commands the lower CP can host a [uTop*] feature that allows the topicalized phrases to use its spec position as an escape hatch. Since Turkish is a language which permits constituents to scramble to various parts of the construction, it is rather plausible to assume that phase heads are optionally specified with [uTop*] or [uFoc*] features in this language. Therefore, in (8) and (9), the PIC is not violated as the phrases Ŭgur' "Uğur-ACC" and Kimi "Who-ACC" move to the the spec position of the DP phase during their movement from the complement clauses to the edge of the main clauses. To exemplify, (8a) is derived in the following stages:

The topicalized phrase Ŭgur'u "Ŭgur-ACC" first moves to the embedded spec CP position and checks the [uTop*] feature with its [Top] feature:

\section{[CP Uğur'u [Top] [щTop*] [TP Tolga'nın \{Uğur'u\}aradığı]]}

The embedded CP then merges with the D0 node, which hosts another [uTop*] feature. The topicalized phrase moves to the spec DP position to check this feature:

[DP Uğur'u[Top] [щTop*] [CP \{Uğur'u[Top]\}[щTop*] [TP Tolga'nın \{Uğur'u\}aradığı]n1]

Finally, it moves to the specifier position of the TopP to check the final [uTop*] feature:

[TopPUğur'u [Top] [世Top*] [TP Ecem [DP \{Uğur'u[Top]\}\{世Top*] [CP \{Uğur'u[Top]\}[世Top*] [TP Tolga'nın \{Ŭgur'u\}aradı̆̆ $]]$ nı] biliyor]]

Since all of the [uwh] features are checked in the derivation, the sentence does not yield any ungrammaticality.

As for adjuncts, they can be topicalized in simplex sentences in Turkish. For example:

(11) [TopP Gizlice [TP Ahmet odaya \{gizlice\} girdi]].

Secretly Ahmet room-DAT enter-PAST

'Ahmet entered the room secretly.'

On the other hand, it is observed that long distance scrambling of some adjunct phrases to sentence initial position results in ungrammaticality:

(12) a.*[TopP Yavaşça[TPKerem [DP[CP arabanın garaja\{yavasca /gir-me-si]-ni] istiyor]] Slowly Kerem car-GEN garage-DAT enter-NFN-3SG-ACC want-PROG 
'Kerem wants the car [to enter the garage slowly]'

b.*[TopP Nasl [TP Kerem [DP [ CP arabanın garaja \{nasll\} gir-me-si]-ni] istiyor?]]

How Kerem car-GEN garage-DAT enter-NFN-3SG-ACC want-PROG

'How does Kerem want the car [to enter the garage \{how\}]?'

(13) a. *[TopP Dün [TP Mustafa [DP [CP Emre'nin Elif'I \{dün\} gör-düğ-ü]-nü] biliyor]]

Yesterday Mustafa Emre-GEN Elif-ACC see-FN-3SG-ACC know-PROG

'Metin knows [that Emre saw Elif yesterday].'

b. *[TopP Ne zaman[TP Mustafa[DP[CP Emre'nin Elif'i\{ne zaman\} gör-düğ-ü]-nü] biliyor?]]

When Mustafa Emre-GEN Elif-ACC see-FN-3SG-ACC know-PROG

'When does Metin know [that Emre saw Elif \{when\}]?'

The reason for the ungrammaticality in (12) and (13) should be related to the charecteristics of the topicalized elements in these sentences. They are all adverbs and they do not have any nominal features. Since a determiner phrase hosts nominal elements, its spec position does not seem to be an available position to be used as an escape hatch by the non-nominal phrases.

On the other hand, contra (12) and (13), nominal adjuncts can scramble to sentence initial position without yielding ungrammaticality:

(14) a. [TopP Murat'tan [TPAyşe [DP[CP benim \{Murat'tan\} para iste-diğ-im]-i] biliyor.]] Murat-ABL Ayşe me-GEN money ask for- FN-1SG-ACC know-PROG

'Ayşe knows [that I asked for money from Murat].

b. [TopP Kimden [TPAyşe [DP[CP benim \{kimden\} para iste-diğ-im]-i] biliyor?]

Who-ABL Ayşeme-GEN money ask for- FN-1SG-ACC know-PROG

'From who does Ayşe know [that I asked for money \{from who\}].'

In Turkish, all ablative case marked nominals are regarded to function as adjuncts. Hence, in (14), the phrase Murat'tan (Murat-ABL) is assumed to function as an adjunct as well. This phrase scrambles to sentence initial position without yielding ungrammaticality. Since the topicalized adjuncts in these sentences have nominal features, they can use the spec DP position as an escape hatch similar to arguments.

As a matter of fact, it is difficult to make clear-cut distinctions between arguments and adjuncts in some cases (Forker, 2014; Hole, 2015). There is not a single set of rules by which we could say that a certain phrase is an argument or an adjunct, as such a decision would depend on the verb in the sentence (Hwang, 2011). As Hoffman (1995) also asserts, some case-marked nominals are in verb's subcategorization set as well. As she asserts, long distance scrambling of adjuncts are possible in those cases where the embedded verb subcategorizes for the phrase in its lexical category (pp.48-49). Therefore, in the present paper, it is asserted that such phrases behave like arguments rather than adjuncts since they are also in the verb's lexical category. In (14), the semantics of an asking for event would not be complete without stating the source from which the money is asked for. For that reason, the phrase Murat'tan (Murat-ABL) can be classified as an argument rather than an adjunct.

To conclude this part, the scrambling of arguments out of complement clauses to sentence initial position can be explained through cyclic movement of the elements through phases in Turkish. On the other hand, while the PIC is violated in the movement of non-nominal adjunct out of such clauses, the 
adjunct that have nominal features can scramble to sentence initial position by making use of the spec DP position as an escape hatch similar to arguments.

\section{Adjunct Clauses in Turkish}

In this part, two types of adjunct structures are analyzed: relative clauses and adverbial clauses. To begin with relative clause constructions in Turkish, the verbs of such constructions are participles and the modified heads always appear in the right-most head position. There are two relative clause forms in Turkish which in broad terms exhibit a subject/non-subject asymmetry. The verb of the relative clause is either marked with a specific subject participle (-(y)An, -Ir/-Ar, -AsI, -mAz, -mIs), or with a specific object participle (-DIK, -(y)AcAK). They are used to relativize the subjects and objects respectively (Çağnı, 2005; Yarbay Duman et. al., 2008). The following sentences exemplify these cases:

(15) Burc

$\begin{array}{lrlll}\text { Burcu [DP [CP kolyeyi } & \text { çal-an] } & \text { kadını] } & \text { tanıyor. } \\ \text { Burcu } & \text { necklace-ACC } & \text { steal-SPAR } & \text { woman-ACC } & \text { know-PROG }\end{array}$

'Burcu knows [the woman [who stole the necklace]].'

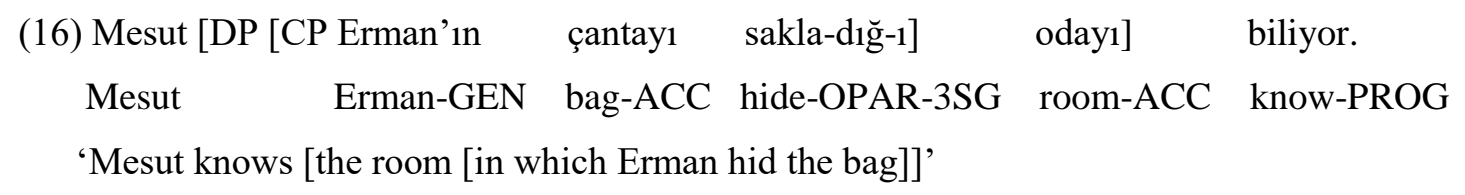

Relative clauses in Turkish are not complementation structures but adjunction structures. In such constructions, CP adjoins to DP (Meral, 2004).

As for adverbial clauses, most of these adjunct constructions are marked for nominalization in ways that are similar to the nominalization properties of subordinate complement clauses (Kornfilt, 1997). The two main nominalization strategies, namely that of marking the verb of the subordinate clause with either-DIK (the factive nominal) or with $-\mathrm{mA}$ (the non-factive nominal) are found in adverbial clauses as well. These nominalized subordinate clauses precede the postpositions:

$\begin{array}{llllll}\text { Meral } & \text { [Ahmet ile } & \text { görüş-tük-ten } & \text { sonra] } & \text { ofisten } & \text { ayrıldı. } \\ \text { Meral } & \text { Ahmet with } & \text { meet-FN-ABL } & \text { after } & \text { office-ABL } & \text { leave-PAST }\end{array}$

'Meral left the office [aftershe met Ahmet]

(18) Mustafa [projenin zamanında bit-me-si için] bütün gün çalışıyor.

Mustafa project-GEN time-3SG-LOC complete-NFN-3SG for all day work-PROG

'Mustafa works all day [in order to complete the project on time]'

The gerundive adverbial clause modifies the predicate of the main clause directly, without the intermediary of a postposition or some other category (Kornfilt 1997:68):

(19)[Babam ameliyattan sağ çık-ınca] rahat bir nefes aldık.

Father-1SG operation-ABL alive getout-GER relieved one breathe take-PAST-1PL

'[When my father got out of the operation alive], we breathed a sign of relief.' 


\subsection{Long Distance Scrambling \& Operator Movement out of Adjunct Clauses}

In Turkish, it is not possible to move elements out of adjunct structures. The extraction of arguments, adjuncts and their operators out of adjunct constructions results in ungrammaticality in this language. To begin with relative clause constructions, it is not possible to move elements out of such structures:

(20) a. *[TopP Çantayı [TP Mesut [DP [CP Erman'ın \{çantayl\} sakla-dığ-1] odayı] öğrendi]].

Bag-ACC Mesut Erman-GEN hide-OPAR-3SG room-ACC learn-PAST

'Mesut learnt [the room [in which Erman hid the bag]].'

b. *[TopP Neyi [TP Mesut [DP [Erman'ın \{neyi\} sakla-dı̆̆-1] oday1] öğrendi]]?

What-ACC Mesut Erman-GEN hide-OPAR-3SG room-ACC learn-PAST

* 'What did Mesut learn [the room [in which Erman hid \{what $\}]$ ?'

(21) a.*[TopP Özür dilemek için [Emel [DP [CP Kerem'in \{özür dilemek için\} yaz-dığ-1] mektubu] okudu]].

Apology beseech-INF for Emel Kerem-GEN write-OPAR-3SG letter-ACC read-PAST

'Emel read [the letter [that Kerem wrotetoapologize]]'

b. *[TopP Neden [TP Emel [DP [CPKerem'in \{neden\} yaz-dığ-1] mektubu] okudu]]? Why Emel Kerem-GEN write-OPAR-3SG letter-ACC read-PAST

* 'Whydid Emel read [the letter [that Kerem wrote \{why\}]]?'

As exemplified in (20) and (21), it is possible to scramble neither arguments, nor adjuncts out of relative clause constructions in Turkish. No matter they are wh- or non wh- phrases, they cannot get out of such constructions.

Long distance scrambling out of adverbial clauses is equally bad in Turkish. It does not make any difference whether the scrambled element is an argument or an adjunct:

(22) a. *[TopP Şirketin [TP Murat [CP \{şirketin\} kapan-ma-s1-ndan sonra] işsiz kald1]].

Firm-GEN Murat close-NFN-3SG-ABL after jobless remain-PAST

'Murat became unemployed [after the closure of the firm].'

b. *[TopPNeyin [TP Murat [CP \{neyin\} kapan-ma-s1-ndan sonra] işsiz kald1]]?

What-GEN Murat close-NFN-3SG-ABL after jobless remain-PAST

*'What did Murat become unemployed [after the closure of \{what $\}]$ ?'

(23) a. *[TopP Kanlar içinde [TP Burcu [CP Erhan eve \{kanlar içinde $\}$ gel-ince] çok korktu]].

Blood-PL within Burcu Erhan home-DAT come-GER very get scared-PAST

'Burcu got very scared [when Erhan came home drenched in blood].'

b. *[TopP Nasıl [TP Burcu [CP Erhan eve \{nasıl\} gel-ince] çok korktu]]?

How Burcu Erhan home-DAT come-GER very get scared-PAST

* 'How did Burcu get very scared [when Erhan came home \{how $\}$ ]?' 
The question that arises at this point is: why nothing can be extracted out of an adjunct clause in Turkish? One may argue here that the ungrammaticality in such constructions stems from post-cyclic adjunction process, which is proposed by Stepanov $(2001 ; 2007)$ under the Late Adjunction Hypothesis.

Stepanov $(2001 ; 2007)$ proposes an eclectic minimalist approach to handle the pre-minimalist CED effects. As he puts forwards, extractability out of subjects and adjuncts are regulated by different mechanisms of grammar in a non-overlapping manner. In this eclectic approach, the subject islands are explained through the Chain Uniformity Approach of Takahashi (1994) or the Criterial Freezing Approach of Rizzi (2006) while the adjunct islands are explained through the Late Adjunction Hypothesis (LAH, hereafter). According to the $\mathrm{LAH}$, adjunction takes place after all substitution, that is, it is operated "post-cyclically". Cyclic movement out of adjuncts is not possible because adjuncts are not present at that point in the derivation. He further asserts that the adjuncts containing uninterpretable features (such as [uwh]) are immune to post-cyclic adjunction process and since their features should be checked in overt syntax (p. 113). According to him, such wh-adjuncts must enter the structure by substitution, hence, cyclically. As a matter of fact, it was first Lebeaux (1991) who claimed that syntactic structures are not always built in a completely cyclic, bottom-up fashion, but rather, some syntactic elements - in particular, adjuncts - can be merged late, or counter-cyclically. This hypothesis has gained considerable interest in the following years (Nissenbaum, 1998; Sauerland, 1998; Fox and Nissenbaum, 1999; Stepanov, 2001; 2007; Fox, 2002; Boskovic, 2004; Henderson, 2007).

The assertions of the LAH seem to hold in Turkish. Clausal adjuncts such as relative \& adverbial clauses merge into the derivation post-cyclically; hence nothing can be extracted out of them as exemplified in (20) - (23). It should be noted here that the adjunct phrases that have been analyzed in (12) - (14) previously in this paper are immune to LAH contra (20) - (23). The adjuncts in (12) - (14) have to move to the matrix spec $\mathrm{CP}$ position to check [uwh] or [uTOP] features and these operations should be done in overt syntax cyclically (Stepanov, 2007, pp. 112-113). The reason for the (un)grammaticality in such sentences stem from other sources as explained above. It is true that the adjunct phrases that originate within relative \& adverbial clauses should be immune to the LAH as well. Since they carry uninterpretable features that should be checked in overt syntax, they should merge into the derivation cyclically as well. However, since they originate within larger adjuncts that do not have any uninterpretable features, they have to merge into the derivation post-cyclically along with the larger adjuncts in which they exist. Therefore, they are not immune to the LAH effects and the ungrammaticality in (20) through (23) can be explained through the LAH.

Along with long distance scrambling cases, the LAH also provides an explanation for the ungrammaticality observed in the extraction of adjunct wh-operators out of embedded relative or adverbial clauses.

Before examining such structures in accordance with the LAH, it should be stated that the argument $\&$ adjunct asymmetry observed in the complement clauses exists for the relative and adverbial clauses as well. While the sentences that contain wh-arguments within their embedded clauses are grammatical in Turkish, the ones that contain wh-adjuncts are ungrammatical:

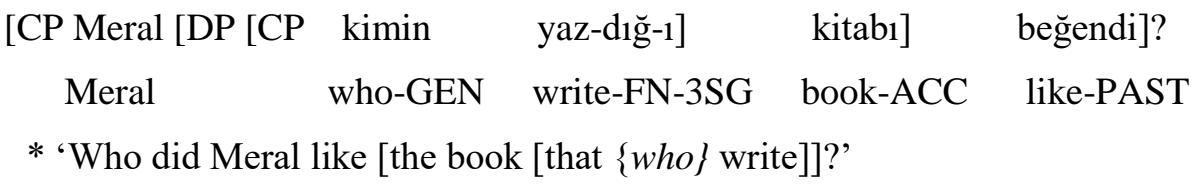

$$
\text { *[CP Emre [DP [CP Elif'in neden yaz-dığ-1] kitab1] beğendi]? }
$$


Emre Elif-GEN why write-FN-3SG book-ACC like-PAST

* 'Why did Emre like [the book [that Elif wrote $\{w h y\}]$ ?'

(26) [CP Serap [CP bu sabah kimi gör-ünce] çok mutlu oldu]?

Serap this morning who-ACC see-GER very happy become-PAST

* 'Who did Serap become very happy [when she saw \{who\} this morning]?'

(27) *[CP Merve [CP Ahmet neden bağır-ınca] çok korktu]?

Merve Ahmet why shout-GER very get-scared-PAST

* 'Why did Merve get very scared [when Ahmet shouted \{why\}]?'

As expressed previously in this paper, Aoun and Li (1993) explain the reason for this asymmetry by claiming that the operators of wh-arguments and wh-adjuncts merge into the derivation in different nodes. While the operators of arguments merge into the derivation directly in matrix $\mathrm{CP}$, the adjunct wh-operators move from the embedded CP to matrix CP. The observations on Turkish show that they are on the right track since arguments \& adjuncts are handled differently in this language. Yet, minimalist explanations are required for the question why they merge into the derivation in different nodes. This point is left for further researches.

In turn to the LAH, it successfully explains the ungrammaticality in (25) and (27). Just as in long distance scrambling of phrases out of embedded relative and adverbial clauses, the extractions of whoperators out of such constructions are subject to the LAH as well. Since the whole adjunct clause merges into the derivation post-cyclically, nothing can be extracted out of it- no matter it is a phrase or an operator. (24) and (26), on the other hand, are not subject to the LAH since nothing is extracted out of embedded adjunct clauses in these interrogative sentences.

\section{Conclusions}

In this paper, long distance extractions out of complement and adjunct clauses in Turkish are examined. In the analysis of the embedded complement clauses, it is proposed that the grammaticality in the movement of the arguments out of such clauses can be explained through the cyclic movement of the elements through phases in Turkish. It is also asserted that the adjuncts that have nominal features can scramble to the sentence initial position by using the spec DP position as an escape hatch likewise arguments. On the other hand, the Phase Impenetrability Condition is violated in the movement of the non-nominal adjuncts out of such clauses.

In the analysis of the adjunct constructions, it is asserted that the LAH successfully explains all types of extractions out of such clauses in Turkish. Arguments, adjuncts or their operators cannot be moved out of relative clauses and adverbial clauses since these clauses adjoin to the derivation post-cyclically. Turkish data support the conclusion drawn by Stepanov (2007): extraction out of adjuncts seems to be banned universally (p. 81).

Table 1 summarizes the assertions of the study: 
Table 1. The summary of the long distance extractions out of complements and adjuncts in Turkish

\begin{tabular}{|c|c|c|c|c|}
\hline \multirow[t]{2}{*}{ Clause Type } & \multicolumn{2}{|c|}{ Arguments } & \multicolumn{2}{|c|}{ Adjuncts } \\
\hline & $\begin{array}{l}\text { Movement of wh- } \\
\text { operators }\end{array}$ & $\begin{array}{l}\text { Long Distance } \\
\text { Scrambling }\end{array}$ & $\begin{array}{l}\text { Movement of wh- } \\
\text { operators }\end{array}$ & $\begin{array}{l}\text { Long Distance } \\
\text { Scrambling }\end{array}$ \\
\hline $\begin{array}{l}\text { (Non)Factive } \\
\text { Nominalized } \\
\text { Clauses }\end{array}$ & $\begin{array}{l}\text { Grammatical; } \\
\text { Merge directly in } \\
\text { matrix CP }\end{array}$ & $\begin{array}{l}\text { Grammatical; } \\
\text { Cyclic movement } \\
\text { through phases }\end{array}$ & $\begin{array}{l}\text { Ungrammatical. } \\
\text { PIC violation }\end{array}$ & $\begin{array}{l}\text { Ungrammatical; } \\
\text { PIC violation }\end{array}$ \\
\hline Complex NPs & $\begin{array}{l}\text { Grammatical; } \\
\text { Merge directly in } \\
\text { matrix CP }\end{array}$ & $\begin{array}{l}\text { Grammatical; } \\
\text { Cyclic movement } \\
\text { through phases }\end{array}$ & $\begin{array}{l}\text { Ungrammatical. } \\
\text { PIC violation }\end{array}$ & $\begin{array}{l}\text { Ungrammatical; } \\
\text { PIC violation }\end{array}$ \\
\hline Relative Clauses & $\begin{array}{l}\text { Grammatical; } \\
\text { Merge directly in } \\
\text { matrix CP }\end{array}$ & $\begin{array}{l}\text { Ungrammatical; } \\
\text { Post-cyclic } \\
\text { adjunction }\end{array}$ & $\begin{array}{l}\text { Ungrammatical; } \\
\text { Post-cyclic } \\
\text { adjunction }\end{array}$ & $\begin{array}{l}\text { Ungrammatical; } \\
\text { Post-cyclic } \\
\text { adjunction }\end{array}$ \\
\hline Adverbial Clauses & $\begin{array}{l}\text { Grammatical; } \\
\text { Merge directly in } \\
\text { matrix CP }\end{array}$ & $\begin{array}{l}\text { Ungrammatical; } \\
\text { Post-cyclic } \\
\text { adjunction }\end{array}$ & $\begin{array}{l}\text { Ungrammatical; } \\
\text { Post-cyclic } \\
\text { adjunction }\end{array}$ & $\begin{array}{l}\text { Ungrammatical; } \\
\text { Post-cyclic } \\
\text { adjunction }\end{array}$ \\
\hline
\end{tabular}

The present study is limited to the analyses of the complement and the adjunct clauses in Turkish. To get the full picture, however, it is necessary to examine the extractions out of subjects as well. Author (2018) carried out a separate study to examine (un)grammatical extractions out of sentential subjects in Turkish. According to this study, the Freezing Principle ${ }^{* *}$ successfully explains all instances of ungrammatical sentential subject extractions in this language. The explanations for the grammatical extractions, on the other hand, are in line with the assertions proposed in this paper. As he argues, the wh-operators are not subject to freezing effects since they merge into the derivation directly in matrix spec CP position. On the other hand, adjunct wh-operators, arguments and adjuncts (no matter wh or non-wh) cannot be extracted out of sentential subjects due to the freezing effects. The following sentences taken from Author (2018) exemplify these cases respectively:

(28) [Cem'in kime sinirlenmesi] herkesi üzdü?

Cem-ACC who-DAT get angry-NFN-3.SG everybody-ACC make-unhappy-PAST

[Who did that Cem get angry with $\{$ who $\}$ ] made everybody unhappy?

$\begin{array}{cllll}\text { (29) *[Cem'in } & \text { neden } & \text { sinirlenmesi }] & \text { herkesi } & \text { üzdü? } \\ \text { Cem-ACC } & \text { why } & \text { get angry-NFN-3.SG } & \text { everybody-ACC } & \text { make-unhappy-PAST }\end{array}$

[Why did that Cem get angry\{why\}] made everybody unhappy?

\footnotetext{
** The Freezing Principle, which was based on Ross (1967), Wexler \& Culicover (1980) and further discussed within minimalism by Takahashi (1994), Boeckx (2003) and Rizzi (2006; 2010), proposes that movement cannot take place from a moved XP. According to this principle, an element which is moved to a position dedicated to some scope-discourse interpretive property, a criterial position, is frozen in place. Since subjects originate within $\mathrm{vP}$ and move to spec TP position, it is impossible to extract anything out of them. This principle provides minimalist explanations for the GB-based subject condition effects.
} 
(30) a. *Ayşe'nin Murat'1 [\{Ayşe'nin\} Ali'yle konuşmas1] \{Murat' $\}$ sinirlendirdi. Ayşe-GEN Murat-ACC Ali-with talk-NFN-3.SG annoy-PAST

[That $\{$ Ayşe $\}$ talked to Ali] annoyed $\{$ Murat $\}$.

b. *Kimin Murat' 1 [\{kimin $\}$ Ali'yle konuşmasi] $\{$ Murat' $l\}$ sinirlendirdi? Who-GEN Murat-ACC Ali-with talk-NFN-3.SG annoy-PAST

[Who did that Ayşe talked to $\{$ who $\}]$ annoyed $\{$ Murat $\}$ ?

(31) a. *Hunharca bizi [Murat'ın Ebru'yu \{hunharca\} öldürmesi] \{bizi\} dehşete düşürdü.

Bloodthirstily us Murat-GEN Ebru-ACC kill-NFN-3.SG horrify-PAST

[That Murat killed Ebru \{bloodthirstily\}] horrified\{us\}.

b. *Nasıl bizi Murat'ın Ebru'yu \{nasll\} öldürmesi $\{$ bizi $\}$ dehşete düşürdü?

How us Murat-GEN Ebru-ACC kill-NFN-3.SG horrify-PAST

How did [that Murat killed Ebru $\{$ how $\}]$ horrified $\{$ us $\}$ ?

In Table 2, these assertions are added to the ones proposed in the present study:

Table 2. The summary of the long distance extractions in Turkish

\begin{tabular}{|c|c|c|c|c|}
\hline \multirow[t]{2}{*}{ Clause Type } & \multicolumn{2}{|c|}{ Arguments } & \multicolumn{2}{|c|}{ Adjuncts } \\
\hline & $\begin{array}{l}\text { Movement of wh- } \\
\text { operators }\end{array}$ & $\begin{array}{l}\text { Long Distance } \\
\text { Scrambling }\end{array}$ & $\begin{array}{l}\text { Movement of wh- } \\
\text { operators }\end{array}$ & $\begin{array}{l}\text { Long Distance } \\
\text { Scrambling }\end{array}$ \\
\hline $\begin{array}{l}(\text { Non)Factive } \\
\text { Nominalized } \\
\text { Clauses }\end{array}$ & $\begin{array}{l}\text { Grammatical; } \\
\text { Merge directly in } \\
\text { matrix CP }\end{array}$ & $\begin{array}{l}\text { Grammatical; } \\
\text { Cyclic movement } \\
\text { through phases }\end{array}$ & $\begin{array}{l}\text { Ungrammatical. } \\
\text { PIC violation }\end{array}$ & $\begin{array}{l}\text { Ungrammatical; } \\
\text { PIC violation }\end{array}$ \\
\hline Complex NPs & $\begin{array}{l}\text { Grammatical; } \\
\text { Merge directly in } \\
\text { matrix CP }\end{array}$ & $\begin{array}{l}\text { Grammatical; } \\
\text { Cyclic movement } \\
\text { through phases }\end{array}$ & $\begin{array}{l}\text { Ungrammatical. } \\
\text { PIC violation }\end{array}$ & $\begin{array}{l}\text { Ungrammatical; } \\
\text { PIC violation }\end{array}$ \\
\hline Relative Clauses & $\begin{array}{l}\text { Grammatical; } \\
\text { Merge directly in } \\
\text { matrix CP }\end{array}$ & $\begin{array}{l}\text { Ungrammatical; } \\
\text { Post-cyclic } \\
\text { adjunction }\end{array}$ & $\begin{array}{l}\text { Ungrammatical; } \\
\text { Post-cyclic } \\
\text { adjunction }\end{array}$ & $\begin{array}{l}\text { Ungrammatical; } \\
\text { Post-cyclic } \\
\text { adjunction }\end{array}$ \\
\hline Adverbial Clauses & $\begin{array}{l}\text { Grammatical; } \\
\text { Merge directly in } \\
\text { matrix CP }\end{array}$ & $\begin{array}{l}\text { Ungrammatical; } \\
\text { Post-cyclic } \\
\text { adjunction }\end{array}$ & $\begin{array}{l}\text { Ungrammatical; } \\
\text { Post-cyclic } \\
\text { adjunction }\end{array}$ & $\begin{array}{l}\text { Ungrammatical; } \\
\text { Post-cyclic } \\
\text { adjunction }\end{array}$ \\
\hline Subjects & $\begin{array}{l}\text { Grammatical; } \\
\text { Merge directly in } \\
\text { matrix CP }\end{array}$ & $\begin{array}{l}\text { Ungrammatical; } \\
\text { Freezing Effect }\end{array}$ & $\begin{array}{l}\text { Ungrammatical; } \\
\text { Freezing Effect }\end{array}$ & $\begin{array}{l}\text { Ungrammatical; } \\
\text { Freezing Effect }\end{array}$ \\
\hline
\end{tabular}

Another limitation of the study is that only the long distance scrambling to sentence initial position has been focused on. Along with the long distance topicalization, scrambling to sentence final position is also possible in Turkish. Such post-verbal movements were examined by Kural $(1992 ; 1997)$ previously. Following his analyses, it appears that sentence initial and sentence final scrambling 
structures display similar characteristics in Turkish. Yet, in a further study, such structures should be analyzed in detail as well.

\section{Ethics Committee Approval}

The author confirms that the study does not need ethics committee approval according to the research integrity rules in their country. (Date of Confirmation: 24.03.2020)

\section{References}

Abels, K. (2012). Phases: An essay on cyclicity in syntax. Berlin: De Gruyter.

Adger, D. (2003). Core syntax: A minimalist approach. Oxford: Oxford University Press.

Akan, T. (2009). On scrambling in Turkish. (Unpublished MA thesis). Boğaziçi University, İstanbul.

Aoun, J. \& Li, Y. A. (1993). Wh-elements in-situ: syntax or LF? Linguistic Inquiry, 24(2), 199-238.

Arslan, C. (1999). Approaches to wh-structures in Turkish. (Unpublished MA thesis). Boğaziçi University, İstanbul.

Arslan Kechriotis, C. (2009). Determiner Phrase and Case in Turkish: A Minimalist Account. Saarbrücken: VDM Verlag Dr. Müller.

Aygen, G. (2002). T-to-C: Extractable subjects and EPP in Turkish. In V. Samiian (Ed.), The proceedings of the Western Conference on Linguistics (pp. 65-80). Fresno: California State University.

Aygen, G. (2011). Reduced relatives and the location of agreement. California Linguistic Notes, 36(1), $1-30$.

Baier, N. (2014). Long distance wh-movement in Seereer. Berkeley Papers in Formal Linguistics, 1(1), $1-44$.

Biskup, P. (2007). Phase feature-driven EPP-features and EPP-feature-driven subjacency in Czech. In P. Kosta \& L. Schürcks (Eds.), Linguistic investigation into formal description of Slavic Languages (pp. 127-146). Frankfurt am Main: Peter Lang.

Boeckx, C. (2003). Islands and chains. Stranding as resumption. Amsterdam: John Benjamins.

Boskovic, Z. (2004). Be careful where you float your quantifiers. Natural Language and Linguistic Theory, 22(4), 681-742.

Boskovic, Z. (2005). On the locality of the left branch extraction and the structure of NP. Studia Linguistica, 59, 1-45.

Boskovic.Z. (2013).Phases beyond clauses. In L. Schurcks, A. Giannakidou, U. Etxeberria \& P. Kosta (Eds.), Nominal Constructions in Slavic and Beyond (pp. 75-128). Berlin: De Gruyter Mouton.

Chomsky, N. (1995). The Minimalist Program. Cambridge, MA: MIT Press.

Chomsky, N. (2000). Minimalist inquiries: The framework. In R. Martin, D. Michaels, \& J. Uriagereka (Eds.), Step by step: Essays on Minimalist syntax in honor of Howard Lasnik (pp. 89-155). Cambridge, MA: MIT Press. 
Chomsky, N. (2001). Derivation by phase. In M. Kenstowicz (Ed.), Ken Hale: A life in language, (pp. 1-52). Cambridge, MA: MIT Press.

Chomsky, N. (2008). On phases. In R. Freidin, C. P. Otero \& M. L. Zubizarreta (Eds.), Foundational issues in linguistic theory. Essays in honor of Jean-Roger Vergnaud (pp. 134-166). Cambridge, MA: MIT Press.

Çağrı, I. M. (2005).Minimality and Turkish relative clauses. (Unpublished Ph.D. dissertation). University of Maryland, College Park.

Den Dikken, M. (2007). Phase extension. Contours of a theory of the role of head movement in phrasal extraction. Theoretical Linguistics, 33, 1-41.

Despic, M. (2011). Syntax in the absence of determiner phrase. (Unpublished Ph.D dissertation). University of Connecticut, Storrs.

Erguvanl1, E. E. (1984). The function of word order in Turkish Grammar. Berkeley: University of California Press.

Forker, D. (2014).A canonical approach to the argument \& adjunct distinction. Linguistic Discovery, 12(2), 27-40.

Fox, D. \& Nissenbaum, J. (1999). Extraposition and scope: A case for overt QR. In S. Bird, A. Carnie, J. D. Haugen, \& P. Norquest (Eds.), The proceedings of the 18th West Coast Conference on Formal Linguistics (pp. 132-44). Somerville, MA: Cascadilla Press.

Fox, D. (2002). Antecedent-contained deletion and the copy theory of movement. Linguistic Inquiry, 33(1), 63-96.

Görgülü, E. (2006). Variable wh-words in Turkish. (Unpublished MA thesis). Boğaziçi University, İstanbul.

Gürel, A. (2003). Is the Overt Pronoun Constraint universal? Evidence from L2 Turkish. In J.M Liceras, H. Zobl \& H. Goodluck (Eds.), The proceedings of the 6th Generative Approaches to Second Language Acquisition Conference (pp. 130-139). Somerville, MA: Cascadilla Press.

Heck, F. \& Müller, G. (2000). Successive cyclicity, long-distance superiority, and local optimization. In R. Billerey \& B.D. Lillehaugen (Eds.), The proceedings of WCCFL 19 (pp.218-230). Somerville, MA: Cascadilla Press

Heck, F., Müller, G. \& Trommer J. (2008). A phase-based approach to Scandinavian definiteness marking. In Charles B. Chang \& Hannah J. Haynie (Eds.), The proceedings of the 26th West Coast Conference on Formal Linguistics (pp. 226-233). Somerville, MA: Cascadilla Proceedings Projects.

Henderson, B. (2007). Matching and raising unified. Lingua, 117, 202-220.

Hoffman, B. (1995). The Computational Analysis of the Syntax and Interpretation of "Free" Word Order in Turkish. (Unpublished Ph.D. dissertation). University of Pennsylvania, Philadelphia.

Hole, D. (2015).Arguments and adjuncts. In T. Kiss \& A. Alexiadou (Eds.), Syntax; Theory and Analysis: An International Handbook (pp. 1285-1321). Berlin/New York: de Gruyter Mouton.

Huang, C. J. (1982). Logical relations in Chinese and the theory of grammar. (Unpublished Ph. D. dissertation). MIT, Cambridge, Massachusetts.

Hwang, J. D. (2011). Making verb argument adjunct distinctions in English; Synthesis paper. Colorado Research in Linguistics, 23, 1-21. Retrieved on February 17, 2018 from: https://journals.colorado.edu/index.php/cril/article/view/307/281 
Kornfilt, J. (1997). Turkish. London: Routledge.

Kornfilt, J. (2003). Subject case in Turkish nominalized clauses. In U. Junghanns \& L.Szucsich (Eds.), Syntactic structures and morphological information (pp. 129-215). Berlin/New York: Mouton de Gruyder.

Kornfilt, J. (2005). Agreement and its placement in Turkic nonsubject relative clauses. In G. Cinque \& R. S. Kayne (Eds.), The Oxford handbook of comparative syntax (pp. 513-541). New York: Oxford University Press.

Kural, M. (1992). Properties of Turkish scrambling. (Unpublished MA thesis). UCLA, Los Angeles.

Kural, M. (1997).Postverbal Constitutes in Turkish and Linear Correspondence Axiom. Linguistic Inquiry, 28(3), 498-519.

Lebeaux, D. (1991). Relative clauses, licensing, and the nature of the derivation. Syntax and Semantics, 25, 209-229.

Meral, H. M. (2004). Resumptive Pronouns in Turkish. (Unpublished MA thesis). Boğaziçi University, Istanbul.

Nissenbaum, J. (1998). Derived predicates and the interpretation of parasitic gaps. In K. Shahin, S. Blake \& E. S. Kim (Eds.), The proceedings of the 17th West Coast Conference on Formal Linguistics (pp.507-521). Stanford, CA: CSLI Publications.

Nunes, J. \& Uriagereka, J. (2000).Cyclicity and extraction domains. Syntax, 3(1), 20-43.

Özsoy, A. S. (1996). A'-Dependencies in Turkish; in B. Rona (Ed.), Current Issues in Turkish Linguistics, vol. 1 (111-125). Ankara: Hitit Yayınevi.

Özsoy, S. (2005). Topic, focus, multiple specifiers, multiple spell-out. Presented as a paper at the Mediterranean Syntax Meeting, University of the Aegean, Rhodes.

Özsoy, S. (2009). Turkish as a (non)-wh-in-situ language . In E. A.Csato, G. Ims, J. Parslow, F. Thiesen \& E. Türker (Eds.), Turcological Letters to Bernt Brendemoen (221-232). Oslo: Novus forlag.

Punske, J. (2011). Escape hatches and the derivation of the DP. Presented as a poster at WCCFL 29, April 22-24, 2011, University of Arizona.

Rizzi, L. (1997). The fine structure of the left periphery. In L. Haegeman (Ed.) Elements of grammar (pp. 281-337). Dordrecht: Kluwer Academic Publishers.

Rizzi, L. (2006). On the form of chains: Criterial positions and ECP effects. In L. L. Cheng \& N. Corver (Eds.), Wh Movement: Moving On (pp. 97-133). Cambridge, MA: The MIT Press.

Rizzi, L. (2010). On some properties of criterial freezing. In E. P. Panagiotidis (Ed.), The complementizer phase: Subjects and operators, vol. 1 (pp. 17-32). Oxford: Oxford University Press.

Ross, J. R. (1967). Constraints on variables in syntax. (Unpublished PhD. dissertation). MIT, Cambridge.

Sauerland, U. (1998). The meaning of chains. (Unpublished Ph.D. dissertation). MIT, Cambridge.

Skinner, T. (2005). Cyclic derivation in partial wh-movement. McGill Working Papers in Linguistics, $19(2), 103-135$.

Stepanov, A. (2001). Late adjunction and minimalist phrase structure. Syntax, 4(2), 94-125.

Stepanov, A. (2007). The end of CED? Minimalism and extraction domains. Syntax, 10(1), 80-126. 
Takahashi, D. (1994). Minimality of movement. (Unpublished Ph.D. dissertation). University of Connecticut, Storrs.

van Urk, C. \& Richards, N. (2015). Two components of long-distance extraction: Successive cyclicity in Dinka. Linguistic Inquiry, 46, 113-155.

Wexler, K. \& Culicover, P. (1980). Formal principles of language acquisition. Cambridge, Massachusetts: MIT Press.

Yarbay Duman, T., Aygen, G. \& Bastiaanse, R. (2008). The production of Turkish relative clauses in agrammatism: Verb inflection and constituent order. Brain and Language, 105 (3), 149-160.

\section{Türkçede uzun mesafeli çalkalama ve işletici taşıma}

\section{$\ddot{O} \mathbf{z}$}

Mevcut çalışma, Türkçedeki yan tümceciklerden tümce başı konuma yapılan çalkalama ve işletici taşıma yapılarına odaklanmaktadır. Çalışmada, üye konumundaki öğelerin evrelerden döngüsel bir şekilde geçerek dilbilgisel olarak tümleyici tümceciklerinden dışarı doğru taşınabildikleri savunulmaktadır. Ayrıca, adsal özellikler taşıyan eklenti öbeklerinin de aynı üyeler gibi Belirleyici Öbeğinin GÖS konumunu kullanarak tümce başı konuma sorunsuz olarak taşınabildiği iddia edilmektedir. Öte yandan, adsal özellik taşımayan eklentilerin benzer yapılarda taşınmaları esnasında Evre Girişimsizlik Koşulunun ihlal edildiği savunulmaktadır. Eklenti tümceciklerine gelindiğinde ise, Geç Eklenti Varsayımının bu tür tümceciklerden dışarı doğru yapılan tüm dilbilgisi dışı taşımaları başarılı bir şekilde açıkladığı öne sürülmektedir. Üyeler, eklentiler ya da onların işleticileri türetime sonradan katıldıkları için ilgi tümceciklerinin ve belirteç tümceciklerinin dışına taşınamamaktadırlar. Türkçe üzerine ortaya atılan bu iddialar eklentilerden dışarı doğru taşıma yapmanın evrensel olarak mümkün olmadığını savunan görüşü desteklemektedir.

Anahtar sözcükler: Türkçe; işletici taşıma; çalkalama; EGK; GEV

\section{AUTHOR BIODATA}

Sinan Çakır graduated from the Department of Foreign Language Education, Middle East Technical University, Ankara, Turkey, in 2002. He received his MA and PhD degrees in the Department of English Linguistics, Hacettepe University, Ankara, Turkey, in 2006 and 2014 respectively. Currently he is working as an assistant professor in Konya Necmettin Erbakan University, Department of Linguistics. His research interests include generative syntax, cognitive linguistics and second language acquisition. 